Research article

\title{
Forest cover correlates with good biological water quality. Insights from a regional study (Wallonia, Belgium)
}

\author{
D. Brogna ${ }^{\text {a, }{ }^{*}, \text { M. Dufrêne }}{ }^{b}$, A. Michez ${ }^{c}$, A. Latli ${ }^{d}$, S. Jacobs ${ }^{\text {e, }}$, C. Vincke ${ }^{g}$, N. Dendoncker ${ }^{\text {a }}$ \\ a University of Namur, Department of Geography, 61 Rue de Bruxelles, 5000 Namur, Belgium \\ ${ }^{\mathrm{b}}$ University of Liège, Gembloux Agro-Bio Tech, UR TERRA, Biodiversity and Landscape Group, 2 Passage des Déportés, 5030 Gembloux, Belgium \\ c University of Liege, Gembloux Agro-Bio Tech, Biosystem Engineering Research Unit, 2 Passage des Déportés, 5030 Gembloux, Belgium \\ d University of Namur, Research Unit in Environmental and Evolutionary Ecology, 61 Rue de Bruxelles, 5000 Namur, Belgium \\ ${ }^{\text {e }}$ Research Group Nature \& Society, Research Institute of Nature and Forest INBO, Kliniekstraat 25, 1070 Brussels, Belgium \\ ${ }^{\mathrm{f}}$ Belgian Biodiversity Platform BBPF, Avenue Louise 231 Louizalaan, 1050 Brussels, Belgium \\ ${ }^{\mathrm{g}}$ Université Catholique de Louvain, Faculty of Bioscience Engineering \& Earth and Life Institute, Belgium
}

\section{A R T I C L E I N F O}

\section{Article history:}

Received 12 July 2017

Received in revised form

5 December 2017

Accepted 4 January 2018

\section{Keywords:}

Macroinvertebrates

Diatoms

Land use

Agriculture

Monitoring network

Water framework directive

\begin{abstract}
A B S T R A C T
Forested catchments are generally assumed to provide higher quality water in opposition to agricultural and urban catchments. However, this should be tested in various ecological contexts and through the study of multiple variables describing water quality. Indeed, interactions between ecological variables, multiple land use and land cover (LULC) types, and water quality variables render the relationship between forest cover and water quality highly complex. Furthermore, the question of the scale at which land use within stream catchments most influences stream water quality and ecosystem health remains only partially answered. This paper quantifies, at the regional scale and across five natural ecoregions of Wallonia (Belgium), the forest cover effect on biological water quality indices (based on diatoms and macroinvertebrates) at the riparian and catchment scales. Main results show that forest cover considered alone - explains around one third of the biological water quality at the regional scale and from 15 to $70 \%$ depending on the ecoregion studied. Forest cover is systematically positively correlated with higher biological water quality. When removing spatial, local morphological variations, or population density effect, forest cover still accounts for over $10 \%$ of the total biological water quality variation. Partitioning variance shows that physico-chemical water quality is one of the main drivers of biological water quality and that anthropogenic pressures often explain an important part of it (shared or not with forest cover). The proportion of forest cover in each catchment at the regional scale and across all ecoregions but the Loam region is more positively correlated with high water quality than when considering the proportion of forest cover in the riparian zones only. This suggests that catchment-wide impacts and $a$ fortiori catchment-wide protection measures are the main drivers of river ecological water quality. However, distinctive results from the agricultural and highly human impacted Loam region show that riparian forests are positively linked to water quality and should therefore be preserved.
\end{abstract}

(c) 2018 Elsevier Ltd. All rights reserved.

\section{Introduction}

\subsection{Freshwaters and water quality}

Despite its crucial importance for the life of all beings

\footnotetext{
* Corresponding author.

E-mail addresses: delphine.brogna@gmail.com (D. Brogna), marc.dufrene@ulg. ac.be (M. Dufrêne), adrien.michez@ulg.ac.be (A. Michez), adrien.latli@unamur.be (A. Latli), sander.jacobs@inbo.be (S. Jacobs), caroline.vincke@uclouvain.be (C. Vincke), nicolas.dendoncker@unamur.be (N. Dendoncker).
}

(Haddadin, 2001; UN-Water, 2014), water and freshwater systems in particular are directly threatened by human activities (Loh et al., 2005; Meybeck, 2003; Millennium Ecosystem Assessment, 2005; Vörösmarty et al., 2010). In response to global degradation of ecosystems and their services, water quality management is at the core of policies such as the US Clean Water Act (1972) and the European Water Framework Directive (Directive, 2000/60/CE) (European Commission, 2000). Water quality can be described by a huge number of variables which can broadly be classified into physical, chemical and biological categories (Boyd, 2015; Chapman, 1992). These groups of variables provide complementary information and 
are inter-related, but biological indicators have the advantage to assimilate long-term disturbance and stress trends in freshwater ecosystems while avoiding the complexity, costliness and high temporal variability linked to physico-chemical measurements (Allan, 2004; Bere and Tundisi, 2010; Giorgio et al., 2016). Among biological indicators, benthic macroinvertebrates are often used to determine the water quality notably because of their sensitivity to pollution, limited mobility, rapid response to external disturbance and dependence on the land environment around the stream (Mahler and Barber, 2017; Sharma and Rawat, 2009). Phytobenthos - of which diatoms are the main component - present a reduced mobility, a short generation time and a rapid response to environmental changes. Diatoms are tightly linked to physico-chemical changes. Being preserved in sediments, they are a good indicator of eutrophication, acidification and organic pollution (Delgado et al., 2012; Lobo et al., 2016). Therefore integrating information from diatoms and macroinvertebrates allows a better assessment of stream ecological integrity by bringing nuances in the responses to multiple pressures (Giorgio et al., 2016; Hering et al., 2006; Marzin et al., 2012; Soininen and Könönen, 2004).

\subsection{Land use and land cover impact on water quality}

Land use and Land cover (LULC) are key landscape elements affecting water quality through their impact on non-point source pollution resulting from complex run-off and landscape interactions. Giri and Qiu (2016) stress the importance of assessing the relationship between LULC and water quality. According to them, improving the understanding of these relationships can help managing water quality in unmonitored watersheds but also providing recommendations to watershed managers and policymakers in the land planning decision process. Related to catchment and riparian degradation in particular, the question addressing the scale at which land use within stream catchments most influences stream water quality and ecosystem health remains only partially answered (Allan, 2004; Johnson et al., 1997; Sheldon et al., 2012; Sponseller et al., 2001). Several studies suggest that prevailing (Kail et al., 2012; Riva-Murray et al., 2002) and past (Harding et al., 1998) LULC characteristics of the whole stream catchments affect surface water quality. Other studies emphasise the impact of riparian LULC on water quality or stream habitat (Dosskey et al., 2010; Jackson et al., 2015). Finally, some studies compare scales of influence (i.e. catchment scale versus riparian scale), obtaining nuanced results on the land use effect on stream water quality according notably to the type of biological indicators and the ecological context of the sampling sites (Kosuth et al., 2010; Marzin et al., 2012, 2012; Sponseller et al., 2001). These studies show that assessing both scales of influence bring deeper insights when studying LULC impact on water quality (Vondracek et al., 2005).

Regarding the type of LULC, negative impact of agricultural intensification is reported in the literature (Stoate et al., 2001) mainly explained by the following processes: increased sedimentation, modified hydrological regimes, loss of high quality habitat, contamination from pesticides, increases in surface water nutriments (mainly N and P) (Allan, 2004; Herringshaw et al., 2011; Mahler and Barber, 2017). Urban land use - despite covering small areas - and urban intensification are also reported to negatively affect water quality (Kosuth et al., 2010; Riva-Murray et al., 2002). Forest, on the contrary, is usually associated with water containing less sediments and fewer nutriments (Neary et al., 2009; TEEB, 2010). This is mainly true for undisturbed forest and most of the time. Indeed, this must be nuanced with regard to sediments and nutrients leaching under certain events such as wildfires (Pacheco et al., 2015; Santos et al., 2015; Shakesby, 2011) or clear- cuts (Borrelli et al., 2017). Some studies showed a positive impact of forest cover on instream water quality (Kosuth et al., 2010; Tong and Chen, 2002), on fish, macroinvertebrate and algal biomass (Stephenson and Morin, 2009). Specifically, forested riparian buffer zones are believed to have a positive impact on water quality through notably the reduction of the sediment load and nutrient concentrations in water (Dosskey et al., 2010; Fernandes et al., 2014; Naiman et al., 2010; Scarsbrook and Halliday, 1999). However, this is nuanced by studies explicitly assessing the effect of riparian forest compared to forest proportion in the whole catchment. For example, Stephenson and Morin (2009), in their study of the partial effects of forest cover on biomass and community structure metrics of algae, invertebrates and fish, never detected a significant partial effect of forest cover at the riparian scale. In conclusion, regarding LULC impact on biological water quality, literature shows general trends, especially opposing agricultural and urban LULC - associated with a negative effect on water quality - and forested land - broadly positively related with water quality, see e.g. Ding et al. (2013), Kosuth et al. (2010) or Theodoropoulos et al. (2015). However, issues of scales of influence and nuances brought by the type of studied biological indicators and the ecological context of study sites remain to be further explored. Also, to our knowledge and as observed by Tanaka et al. (2016), only few studies integrate information from macroinvertebrates, diatoms and physico-chemical water quality variables to get a broader picture of the forest cover impact on water quality. These questions are of major concern for land managers in enhancing or maintaining good water quality and in particular regarding environmental land use conflicts that have been reported to contribute to water quality degradation (Pacheco and Sanches Fernandes, 2016) and biodiversity decline (Valle Junior et al., 2015).

\subsection{Objectives}

The main objective of this paper is, at the regional scale and across five natural ecoregions, to quantify the forest cover effect on biological water quality indices at the riparian and catchment scales. This objective is addressed through: (i) the comparison of this link's power at riparian and catchment scales, (ii) the assessment of this link while controlling for spatial, local morphology and population pressure variations, (iii) the quantification of independent and shared effects between forest cover and the physicochemical water quality, anthropogenic pressures (agriculture and population density) and local morphology.

\section{Material and methods}

\subsection{Study area}

The study area is the southern region of Belgium (Wallonia) covering $16898 \mathrm{~km}^{2}$ (ca. 55\% of Belgium's area, see Fig. 1 A). We work on 173 headwaters stations located on the publically managed river network where biological and physico-chemical water quality data are monitored by the Walloon Public Service [WPS (SPW - DGO3, n.d.), Fig. 1 B). These stations monitor headwater waterbodies and have non-overlapping upstream catchments (Fig. 1 B \&D). Fig. 1 D shows forest cover distribution in waterbodies.

Wallonia presents relatively contrasted landscapes and can be divided into five natural ecoregions (Fig. 1 A and Table S1 in supplementary materials). Noirfalise (1988) delineated these ecoregions according to pedological, botanical and agro-ecological criteria. Main ecological differences are found across an elevation gradient from the Loam to the Ardenne ecoregion. The Loam and the Condroz ecoregions located in lower elevation areas (Fig. $1 \mathrm{C}$ ) 


\section{A. ECOREGIONS}

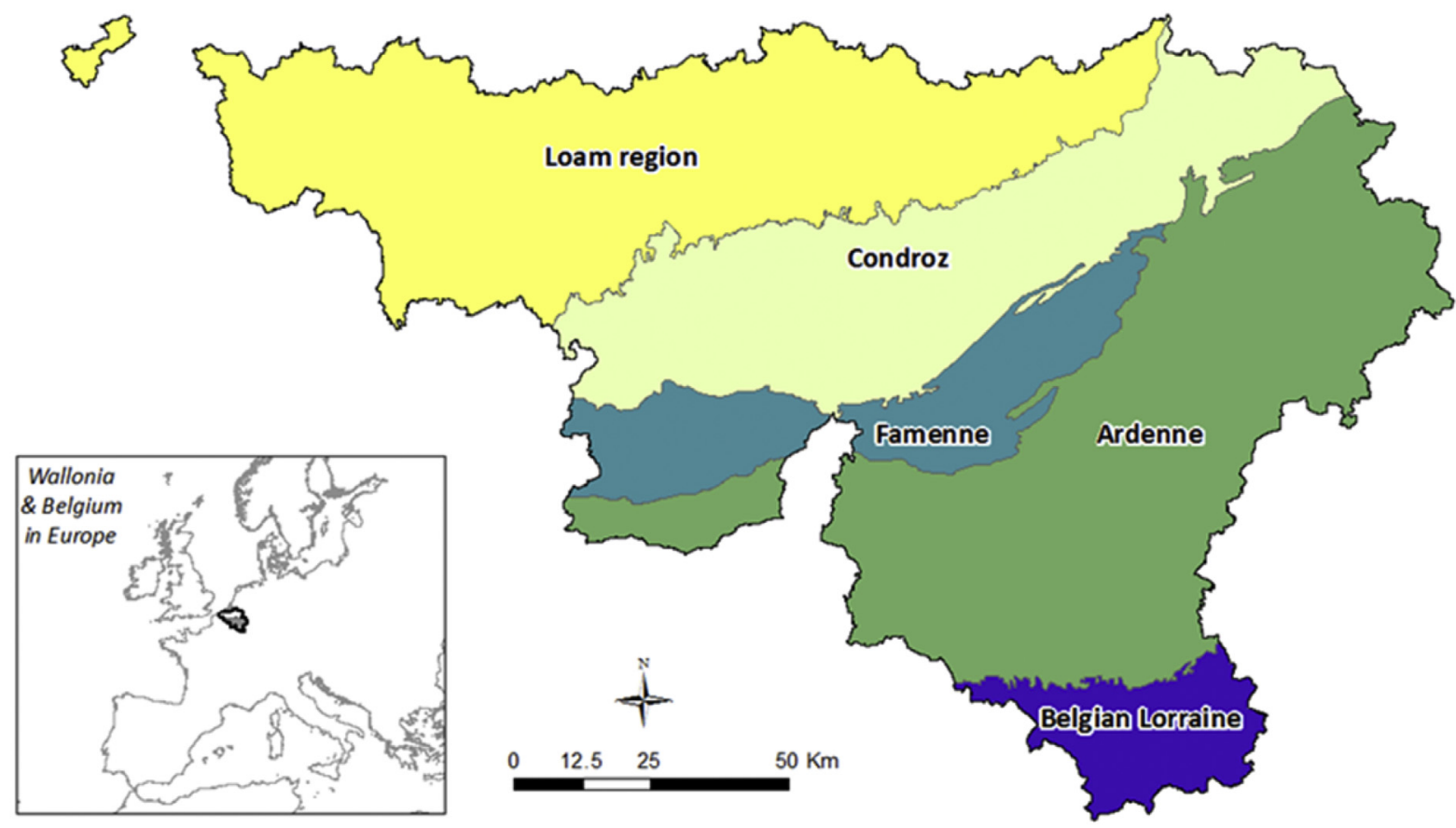

\section{B. MONITORING STATIONS - CATCHMENTS \& HYDROGRAPHY}

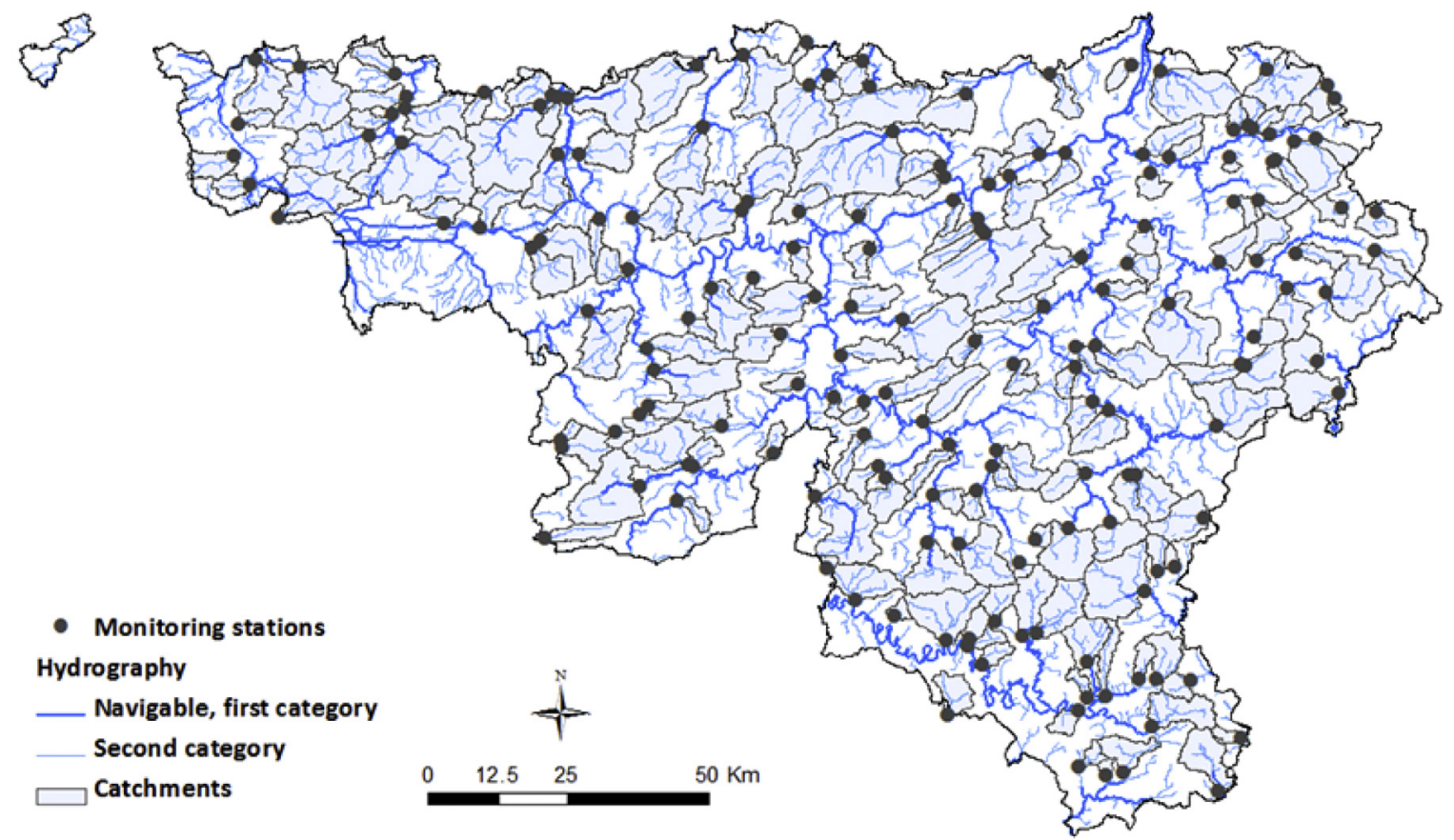

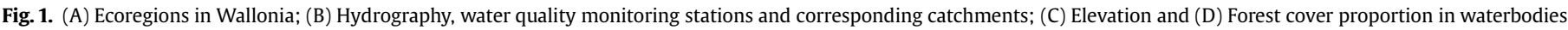
defined by the EU Water Framework Directive.

mainly comprise agricultural and urban land uses, and present high human population densities. The Ardenne ecoregion mostly consists in forested and grassland landscapes with lower population density, but remains a highly managed region. The Famenne and the Belgian Lorraine ecoregions, bordering the Ardenne in the North and South respectively, present an intermediate context with an equal coverage of agricultural and forested land.

Agriculture in Wallonia is generally intensive with a negative 


\section{ELEVATION}

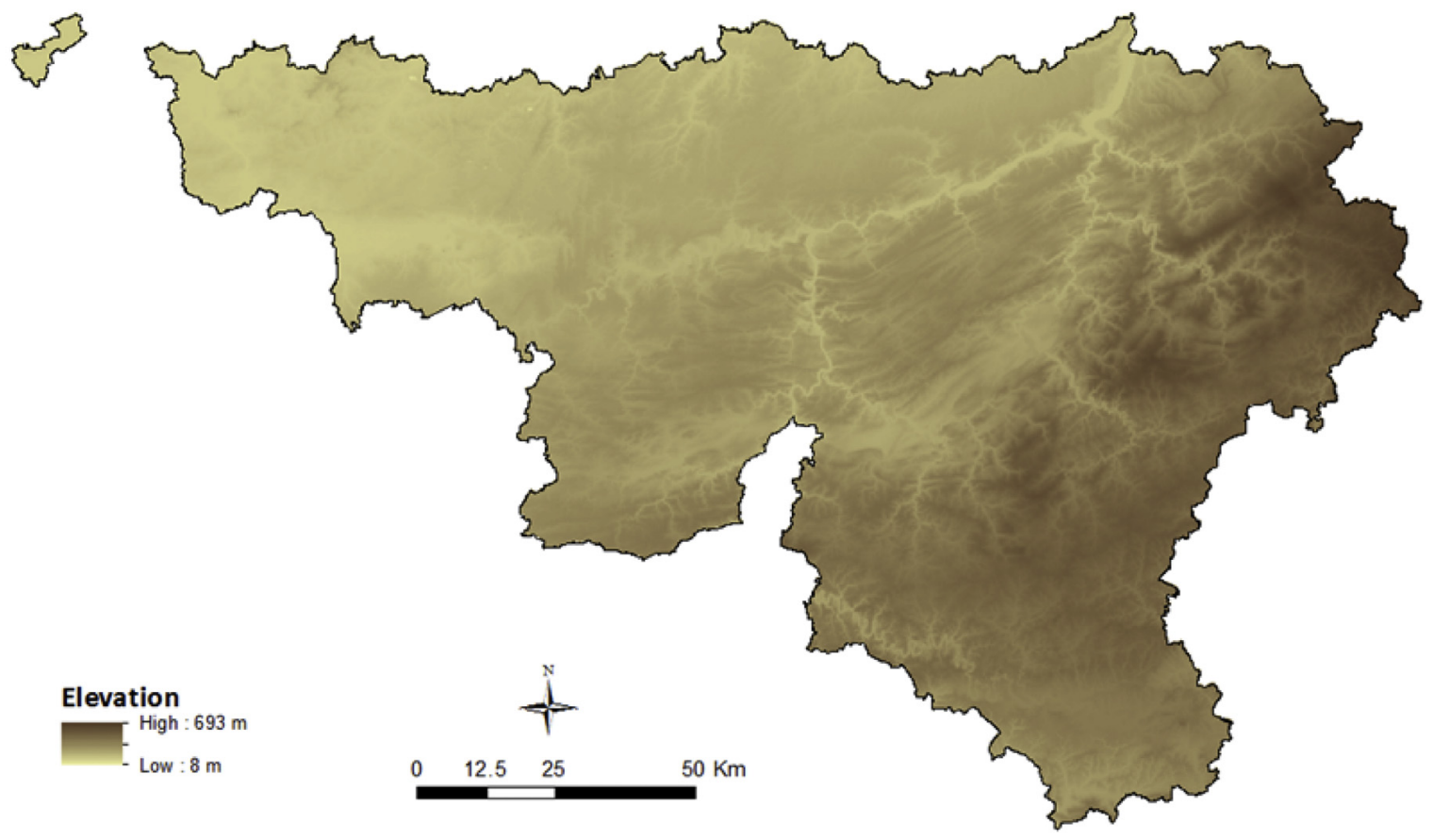

\section{FOREST COVER IN WATERBODIES - EU-WFD}

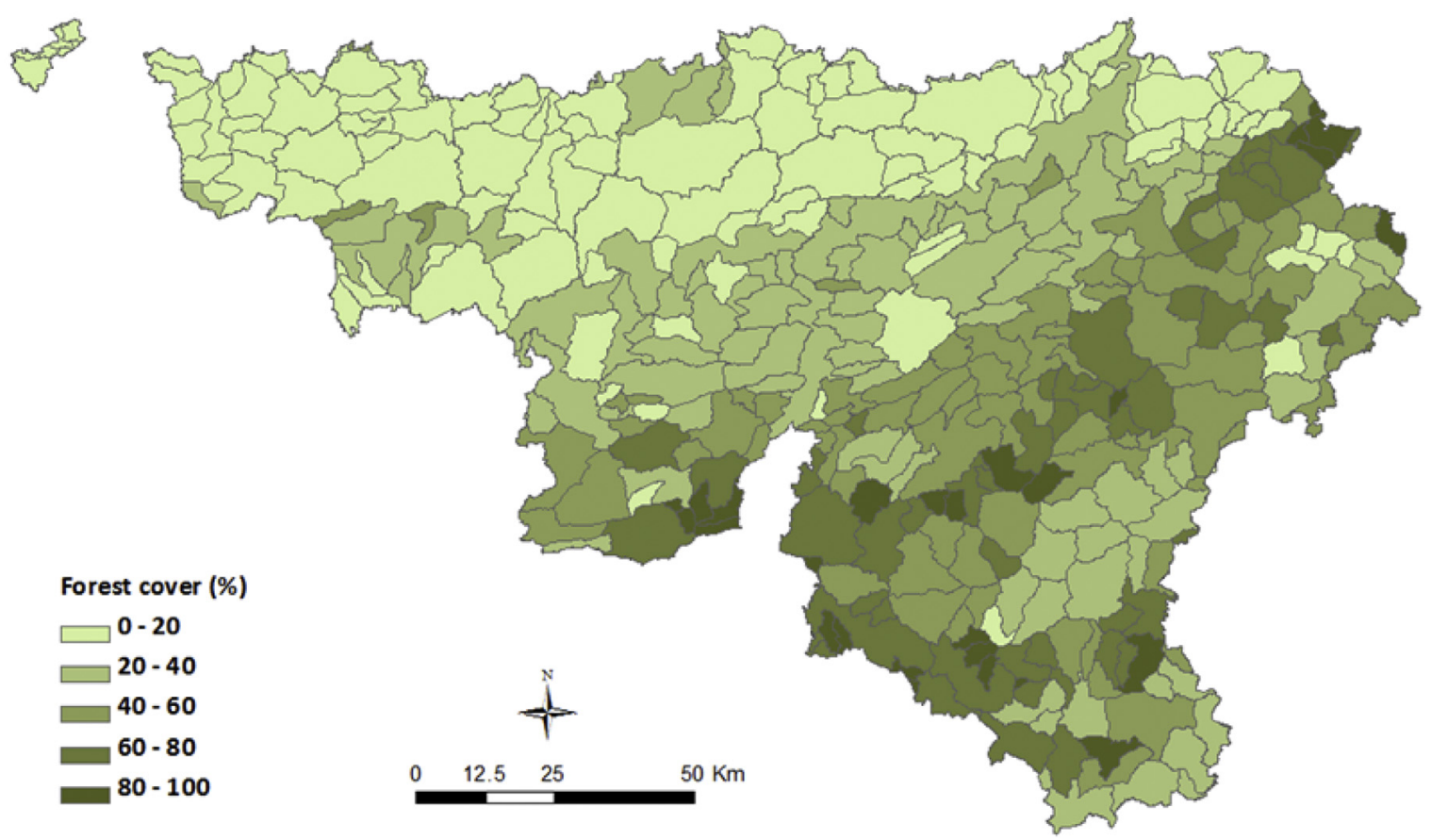

Fig. 1. (continued).

impact on water quality through the use of mineral fertilizer, in particular nitrogen $(\mathrm{N})$ and phosphorus $(\mathrm{P})$, causing eutrophication and drinking water quality degradation. Agricultural land is relatively heterogeneous across Wallonia and mainly consists of cropland and grassland. Their spatial distribution is relatively heterogeneous. In the Loam region, most agricultural lands (three 
quarters) are intensive cropland whereas in the Ardenne, Belgian Lorraine and Famenne ecoregions, most agricultural lands are grassland (up to $85 \%$ in the Ardenne). In the Condroz ecoregion, grassland and cropland share comparable areas.

Most of the forest cover in Wallonia is represented by either needle-leaved (44\%), mainly located in the Ardenne, or broadleaved forests $(53 \%)$ spread across Wallonia, the rest being classified as mixed forest (3\%) [source: Top10VGIS, see Alderweireld et al (2015) for further information on forest composition].

\subsection{Datasets}

The variables used in this study and the datasets on which they are based are described in sections 2.2.1 to 2.2.3 (see also Table S2 in supplementary material for a summary). These variables are either response variables (biological water quality indices) or explanatory variables linked to LULC, physico-chemical water quality, anthropogenic pressures in upstream catchment, local morphology or elevation. Every observation line in the dataset (monitoring station*year of measurement) is characterized by all these variables.

\subsubsection{Biological and physico-chemical water quality}

Biological and physico-chemical water quality are described by variables measured as part of the monitoring of water bodies quality performed by the WPS for the EU-WFD (SPW-DGO3Direction de l'Etat Environnemental, 2016). Dahm et al. (2013) highlight the potential of broad datasets such as EU-member states 'water quality monitoring data and argue that those represent the European water bodies much better than restricted datasets from local studies and projects. Processing these datasets with appropriate methods offers an opportunity to study LULC impact on ecological integrity at different scales and combining various indicators types. We selected six years of data (2009-2014) corresponding to the last EU-WFD cycle (data from 2015 are not validated yet). Biological water quality is described through annual values of the macroinvertebrates index and the diatoms index. The macroinvertebrates index is based on the French IBGN [i.e. "Standardized Global Biological Index", see AFNOR (2004, 1985)] that was adapted to Wallonia. This implies sampling of the benthic macrofauna by station according to a sampling scheme that takes into account the diversity of habitats defined by the substrate nature and the flow velocity. This methodology - certified ISO $9001-$ was described in details by Vanden Bossche (2005). The IBGN score, with a range from 0 (no indicator taxa) to 20 , is obtained by crossing two sub-indices: the "faunal indicator group" reflecting pollution sensitivity and the "taxonomic diversity class" reflecting habitat quality. The higher the value the higher the water quality. The index based on benthic diatoms is the IPS ("Specific Polluosensitivity Index"). This index was built by Coste (CEMAGREF, 1982) and is based on the index method of DESCY (1979). It has the advantage to account for all species found in inventories and varies from 1 (highly polluted water) to 20 (high quality water).

We selected all stations that monitor a headwater waterbody. The resulting dataset is composed of 319 measurements related to 173 stations spread across Wallonia (Fig. 1 B and D). Each biological water quality observation (IBGN or IPS values) is a representative value for the year, methodologies of sampling are designed in that objective [e.g. macroinvertebrates samples are taken in low flow period - i.e. from June to October (Vanden Bossche, 2005)]. The number of observations by station across the studied period varies between 1 and 5 with a median value of 2 . We kept all observations across the studied period to increase the representativeness of the sampling of some monitoring stations. Physico-chemical water quality indices were aggregated to match biological water quality data while the other explanatory variables (i.e. land cover proportions, population density, morphological variables and elevation) are considerd as invariable and combined in some cases with two to five water quality indices measurements.

Stations represent different kinds of "control" type with regard to the EU-WFD. Indeed, stations are almost equally divided into "additional" and "operational" control corresponding to relatively 'good state' waterbodies and impacted waterbodies respectively. Surveillance stations are also part of the dataset. Both biological water quality indices were divided by the reference value for the corresponding river type (SPW-DGO3-Direction de l'Etat Environnemental, 2016) to obtain comparable indices across the region (Kosuth et al., 2010). These ratios are, in this paper, further referred to as IBGN-R and IPS-R; values close to 1 represent really high water quality. The physico-chemical water quality is described by annual average values of the following variables: Dissolved Oxygen, Nitrates, Chloride, Sulfates, Temperature, Total Phosphorus, Nitrites, Ammonium, Dissolved Organic Carbon and Suspended Materials. We applied Log- or square-based transformations when needed to improve normality of variables' distribution.

\subsubsection{Land use and land cover data and pressures}

We used the Top10VGIS land cover data set from 2010 from the Belgian National Geographic Institute (NGI, www.ngi.be) to characterize the land cover influencing the water quality at the monitored station. This vector data set, which covers the whole of Belgium, is based on the NGI topogeographic data that classifies LULC into 37 classes. In this study, we reclassified it in six classes of interest by either keeping the original land cover classes as such or grouping them. The classes of interest are forest (i.e. needle-leaved, broad-leaved and mixed forest), cropland, grassland, artificial surfaces, water surfaces and shrubs-heathlands. We assumed as in other studies (Brogna et al., 2017a, 2017b) that the evolution of the retained classes in the region was minor throughout the studied period (2009-2014).

To relate the LULC to water quality, we intersected the Top10VGIS dataset with three distinct related upstream spatial units: riparian buffer, outside this buffer, and the whole catchment. To our knowledge in most of studies, authors use a fixed-distance buffer to study riparian LULC impact on water quality [e.g (Boyer-Rechlin et al., 2016; de Oliveira et al., 2016; Marzin et al., 2013; Sliva and Dudley Williams, 2001; Sponseller et al., 2001)]. In this study, we treat channels of relatively contrasted morphology even within the same ecoregion and range of catchment sizes, and a similar buffer width might or might not represent the same riparian zone extent according to the riparian topography and the parameters of the associated river (channel size, hydrological regime). Hence, we based our definition of the riparian area on a regional geographic layer representing areas subject to flooding by overflowing for return periods of 25, 50 and 100 years (see "aléa d'inondation", http:// geoportail.wallonie.be). We selected the spatial area corresponding to the 100 years flooding (see "functional riparian buffer" in Fig. 2) which is a rather large delineation of the riparian zone. Regarding the catchment scale ("whole catchment" in Fig. 2), we automatically extracted upstream catchments from a regional LiDAR digital terrain model (1 m GSD) provided by the WPS (see Fig. $1 \mathrm{C}$, http:// geoportail.wallonie.be).

The most represented LULC classes in our dataset (see section 2.1) are forest and agricultural cover (grassland and/or cropland cover) (see boxplots in Supplementary Materials Fig. S3). The Loam region presents the lowest forest cover proportion in upstream catchments but with a certain variability.

We computed population density in each upstream catchment based on a statistical administrative Belgian database from 2008 (Statistics Belgium, n.d.) to complement agriculture proportion and 

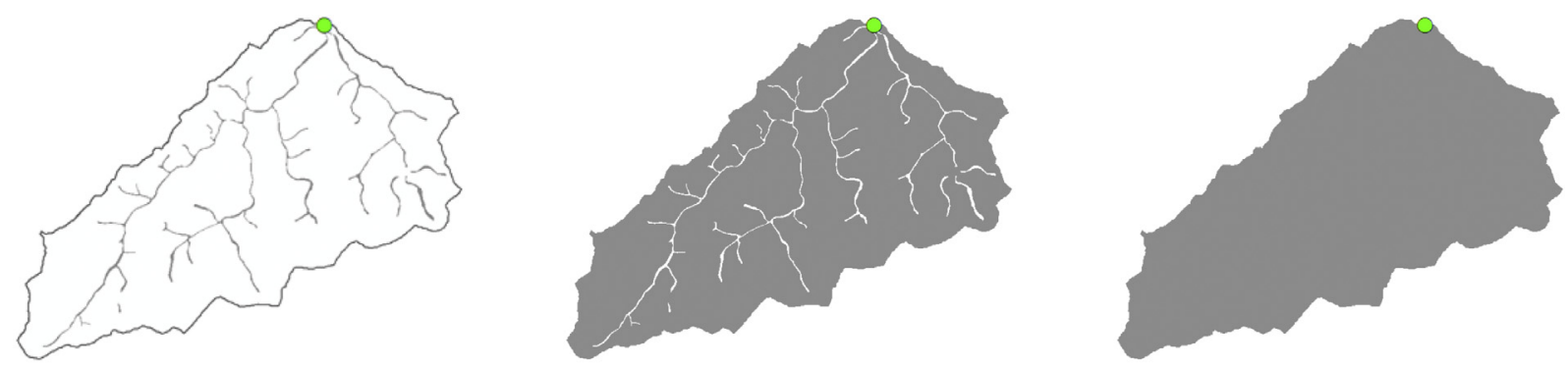

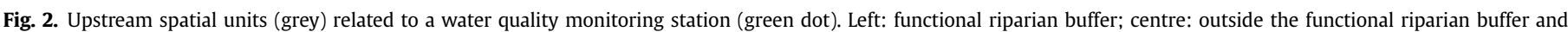
right: whole catchment. (For interpretation of the references to colour in this figure legend, the reader is referred to the Web version of this article.)

create a proxy matrix for anthropogenic pressures. Population density was computed for each statistic sector scale (smallest administrative spatial unit where population data are available). Then, density values were linked to sectors centroids to derive a spatial grid that was used to extract median density values for each upstream catchment.

\subsubsection{Physical characteristics of stations and catchments}

We used the regional LiDAR digital terrain model to compute average elevation over the catchments. We then computed three main local morphological parameters of the river network following the approach of Michez et al. (2017). We extracted from the same LIDAR digital terrain model and for every monitoring station, the channel width (m) and the emerged channel depth (m) associated to the corresponding river reach. We also computed the local sinuosity (\%) of the upstream river sector associated to each station.

\subsection{Spatial scales of analysis}

Every analysis in the study was run over six different extents: at the regional (Wallonia) study scale and within each of the five ecoregions. This allows providing a general picture for the region and to analyze trends and differences across ecoregions. Regarding the forest cover explanation power of biological water quality and its stability [objectives (i) and (ii)], we tested it on two distinct upstream spatial units within each catchment: the functional riparian buffer and outside this buffer (Fig. 2 left and centre). For the first analysis [objective (i)], we also performed analysis on the percentage of forest over the whole catchment (Fig. 2, right) - third upstream spatial unit (section 2.4.1) to compare it with the percentage of forest outside the functional riparian buffer.

\subsection{Forest cover link with biological water quality}

We ran statistical multivariate analysis to fulfil the objectives of this study and exploit the potential of broad datasets such as EUmember states' water quality monitoring. These analyses are described in sections 2.4.1 to 2.4.3 and shown in Fig. 3.

\subsubsection{Functional riparian buffer or catchment scale?}

We performed redundancy analysis [RDA, see Legendre and Legendre (2012), R package vegan (Oksanen et al., 2017)] for the six extents and for the three upstream spatial units where forest

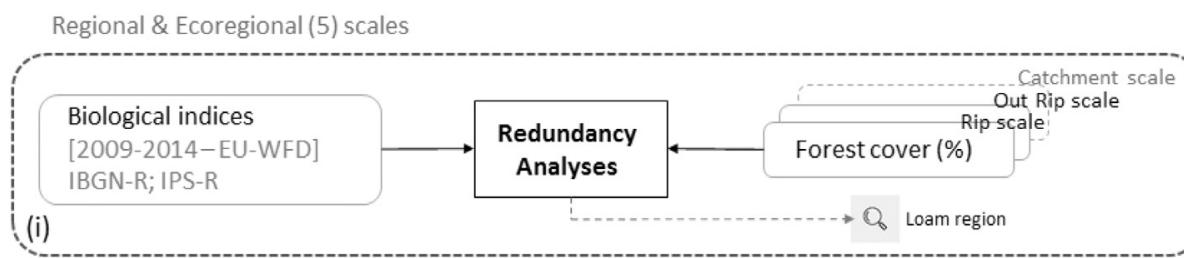

Regional \& Ecoregional (5) scales

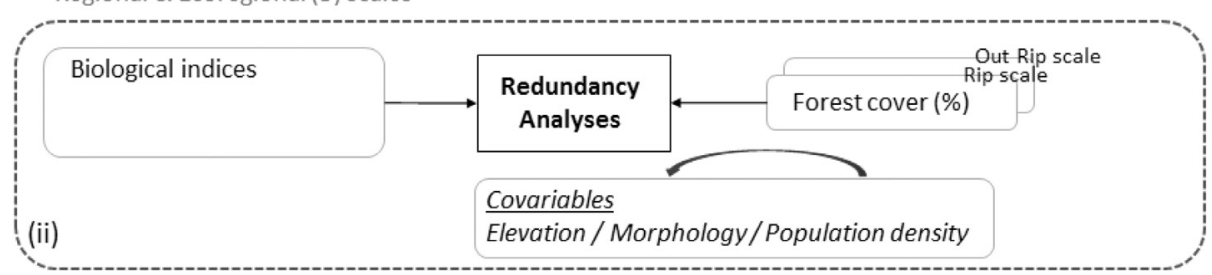

Regional \& Ecoregional (5) scales

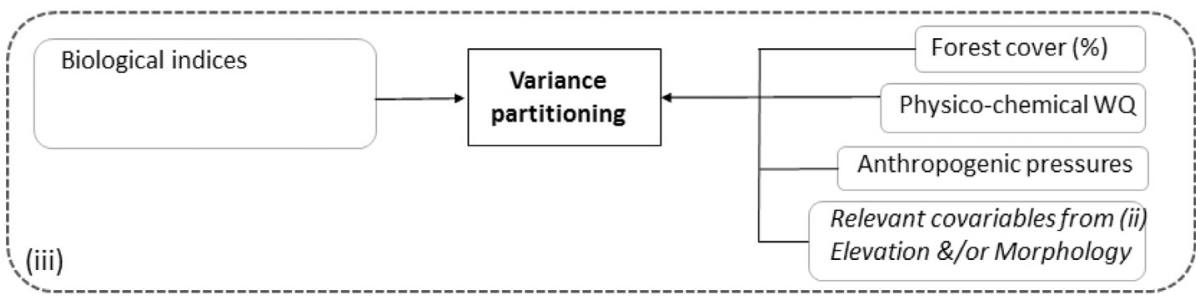

Fig. 3. Main analyses to fulfil the three study objectives; Rip: riparian.
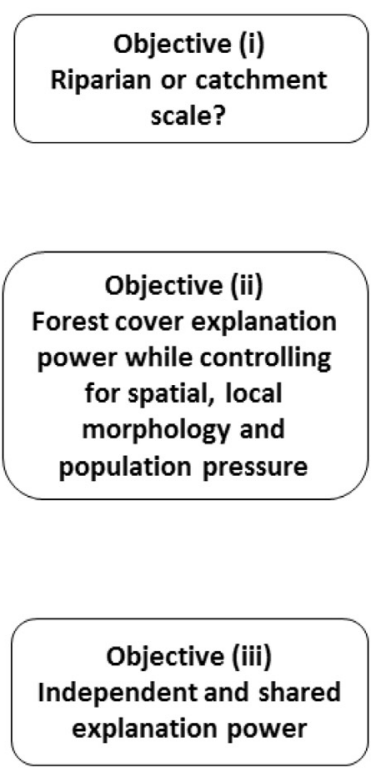
cover was computed: functional riparian buffer, outside this buffer, and the whole catchment. Redundancy analysis is a multivariate analysis that allows capturing the linear relationship between several dependent variables and one or several explanatory variables. In this case, RDA quantifies the percentage of biological water quality variability explained by forest cover proportion. RDA also allows quantifying and excluding the variability explained by other covariables. We confirmed the absence of non-linear relationships between response and explanatory variables prior to applying RDA. We ran these RDA on centered and scaled variables because of the heterogeneity of the variables units.

Bio WQ Forest

where Bio $\mathrm{WQ}=$ matrix of biological water quality indices (i.e. IBGN-R and IPS-R), and Forest = percentage of forest cover in the upstream spatial unit.

Following results interpretation, complementary RDA will be ran to quantify the explanation power of main LULC types' proportions inside and outside the functional riparian buffer on biological water quality.

\subsubsection{Forest cover explanation power when controlling for spatial autocorrelation, local morphology and population pressure}

We tested the impact of several variables or group of variables on the forest cover explanation power by putting them as covariables in RDA's. Covariables are variables whose variation is to be controlled for in a partial analysis (Borcard et al., 2011). As in Brogna et al. (2017a), we tested the effect of elevation as a mean of controlling spatial autocorrelation (Equation type (2), with "covariable" being average elevation of the upstream catchment). We present these results for the six extents even though this is especially true at the Walloon regional scale. Indeed, a strong continuous ecological gradient exists in Belgium and is highly correlated to elevation (Dufrene and Legendre, 1991; Noirfalise, 1988). Dufrêne and Legendre (1991) showed that elevation, although not exceeding $700 \mathrm{~m}$ in Belgium, explains almost all the geographic structure of several ecological variables given their spatial autocorrelation.

Bio WQ Forest + Condition(Covariable)

where Bio $W Q=$ matrix of biological water quality indices (i.e. IBGN-R and IPS-R), Forest = percentage of forest cover in the upstream spatial unit, and 'Covariable' = variable whose effect on Bio WQ is removed before quantifying the forest cover effect.

We also tested the effect of local morphology by putting the following variables as covariables (Equation type (2)): sinuosity of the river sector associated to the station, local channel width, emerged channel depth and upstream catchment area. Following interpretation of these results, significant covariates will be kept for further analysis (section 2.4.3). Finally, we tested the effect of population density in the same way.

These tests allow deepening the interpretation of the forest cover link with water quality.

\subsubsection{Forest cover: independent and shared explanation power} with anthropogenic pressures and physico-chemical water quality

We ran variation partitioning (Legendre and Legendre, 2012) to quantify independent and shared forest cover explanation power with physico-chemical water quality, anthropogenic pressures and other potentially relevant covariables from the analysis described in section 2.4.2. We computed adjusted redundancy statistics $R^{2}$ to provide unbiased estimates of the explained fractions of variance (Peres-Neto et al., 2006). Anthropogenic pressures are represented by the proportion of agricultural land (i.e. cropland and grassland total cover) and the population density in the upstream catchment. Given the high correlation between physico-chemical water quality variables, we reduced information by selecting, for each extent of study, the two variables most post-correlated with the first and second axes of a Principal Component Analysis (PCA) on biological water quality, respectively. Results of variation partitioning are only presented for variables linked to significant individual and partial RDA models (i.e. p value <.05). Furthermore, we illustrated the link between explanatory variables (physico-chemical water quality, anthropogenic pressures and local morphology variables) and biological water quality through PCA on biological variables and post-correlations.

\section{Results}

\subsection{Functional riparian buffer or catchment scale?}

Fig. 4 shows differences in forest cover impact on biological water quality according to the three distinct upstream spatial units where forest cover is computed. Figures represent the proportion of variability in the biological water quality dataset explained by forest cover proportion. We do not present the Famenne ecoregion results, as the models were not significant (evaluation with permutation tests) (see further details in Table 2). Forest cover explains around a third of the biological water quality variability in Wallonia. The forest cover link with biological water quality is far more demonstrated in the Belgian Lorraine (around 70\% of explained variability). Fig. 4 also illustrates that variability explained by proportion of forest cover in the whole catchment and in the area outside the functional riparian buffer are highly similar. Hence, to ease the reading and work on spatially independent areas (i.e. non overlapping areas), we will only keep the following upstream spatial units for further analyses: inside the functional riparian buffer and outside it.

In Wallonia and for every ecoregion but the Loam region, the forest cover proportion in the area outside the functional riparian buffer slightly better explains the biological water quality than the proportion of forest cover in the functional riparian buffer.

The overall low forested Loam region shows distinctive results compared to the other ecoregions. Therefore, we provide complementary analyses results in Table 1 to refine the interpretation of the forest cover link with biological water quality in this ecoregion. This table presents details of RDA results quantifying biological water quality variability explained by forest, cropland and grassland cover respectively. We distinguished between cropland and grassland as their distribution is variable according to the upstream spatial unit considered (see Fig. S3B in supplementary materials). Results compare riparian forest cover and forest cover outside riparian buffer. $F$ value and significance of the models from permutation tests are also provided.

Forest cover proportion inside the riparian buffer explains 21\% of the biological water quality variability in this ecoregion with a highly significant model ( $p$ value of 0.001 ). Cropland explain $11 \%$ while grassland cover explains only $4 \%$ with a barely significant model ( $p$ value between 0.05 and 0.1 ). Regarding LULC outside the functional riparian buffer, results show that forest cover explains $7 \%$ of the water quality variability and is the only significant model. Indeed, cropland-based model is non significant and the grassland one is again at the limit of model significance.

\subsection{Forest cover explanation power when controlling for spatial autocorrelation, local morphology and population pressure}

Details of RDA results quantifying forest cover explanation 


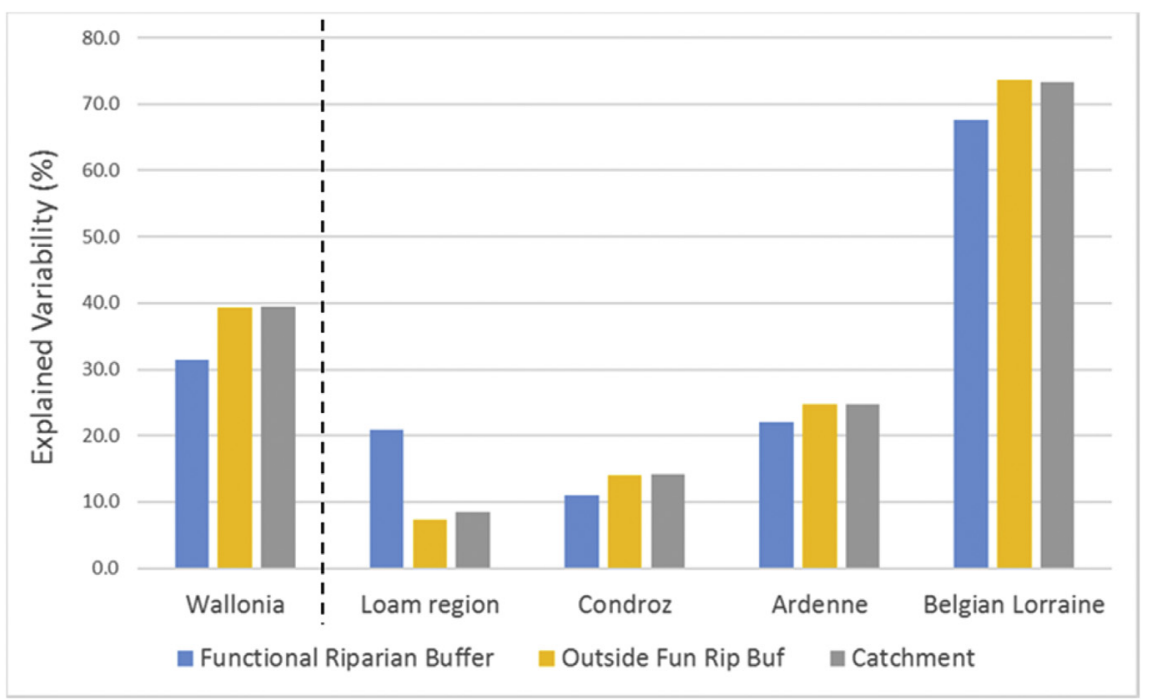

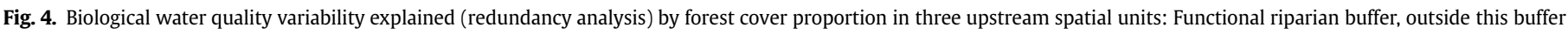
(Outside Fun Rip Buf) and in the whole catchment. Results from significant models for Wallonia scale and in ecoregions.

Table 1

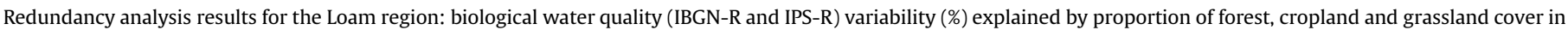

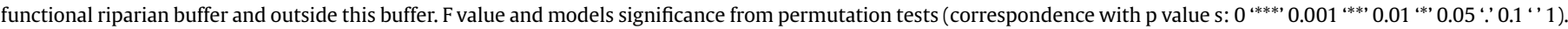

\begin{tabular}{|c|c|c|c|c|}
\hline Scale where proportion of forest & LULC & Variability explained (\%) & $\mathrm{F}$ & Model Significance \\
\hline \multirow[t]{3}{*}{ Functional Riparian Buffer } & Forest & 21 & 20 & $* * *$ \\
\hline & Cropland & 11 & 9 & $* *$ \\
\hline & Grassland & 4 & 3 & . \\
\hline \multirow[t]{3}{*}{ Outside Functional Riparian Buffer } & Forest & 7 & 6 & $* *$ \\
\hline & Cropland & 3 & 2 & Non sign \\
\hline & Grassland & 4 & 3 & . \\
\hline
\end{tabular}

power of biological water quality with or without covariable for the six extents are presented in Table 2. Results compare functional riparian forest cover and forest cover outside this buffer link with biological water quality. $F$ value and significance of the models from permutation tests are also provided. Fig. 5 presents the global trend, found in every model, through the regional forest cover computed outside the riparian buffer - link with biological water quality when controlling for spatial autocorrelation through elevation. The factorial plan is constituted by the constrained axis (RDA1) and the first residual axis (PC1).

Forest cover is systematically related to higher biological water quality whether for diatoms index (IPS-R) or macroinvertebrates index (IBGN-R) (see e.g. Fig. 5). When controlling for spatial autocorrelation through the elevation factor at the Walloon scale, the biological water quality variability explained by forest cover drops from 31 to $13 \%$ and from 39 to $14 \%$ if computed in the functional riparian buffer or outside this buffer respectively. Elevation effect is, as expected, less important within the ecoregions as these are more homogeneous in terms of elevation and ecological factors. The local morphology impact on forest cover explanation power of biological water quality is small or even negligible at the Walloon scale and for the Ardenne and Condroz ecoregions. For the latter, removing morphological effect even increases the proportion of variability explained by forest cover. This increase is due to the fact that removing covariables effect might also remove part of the residual variability, hence enhancing the proportion of variability explained by the active variable. The situation is different in the Belgian Lorraine where removing local morphology effect decreases the proportion of variability explained by forest cover by 14 and $19 \%$ when forest cover is computed in the functional riparian buffer or outside this buffer respectively. Despite this, Belgian Lorraine remains the ecoregion where forest cover best explains biological water quality. Population density effect on the relationships between forest cover and biological water quality is at every extent relatively important. Indeed, it reduces the proportion explained by forest cover (outside the functional riparian buffer) from around one third of its importance at the Wallonia scale, in the Ardenne and Belgian Lorraine and slightly less in the Condroz. Models in the Famenne ecoregion are non-significant.

\subsection{Forest cover: independent and shared explanation power with anthropogenic pressures and physico-chemical water quality}

This subsection presents results from variation partitioning computed to isolate independent and shared explanatory power of the biological water quality between: (i) forest cover computed in or outside the functional riparian buffer according to the strength of the link with biological water quality (cf. Fig. 4), (ii) anthropogenic pressures represented by population density and agricultural proportion in the catchment and (iii) physico-chemical water quality. Following the analyses presented in previous sections, we added local morphology variables when relevant (i.e. for the Loam region and Belgian Lorraine region). Derived plots are presented in Fig. 6. Figures inside each subspace are positively adjusted coefficients of determination (expressed in percentage) and represent the variability explained by each subspace. Results for every study scale are presented except for the Famenne ecoregion where models are not significant. Biological water quality dataset PCA biplots with - as supplementary variables -each potential variable in this variation partitioning analysis are provided in supplementary materials 


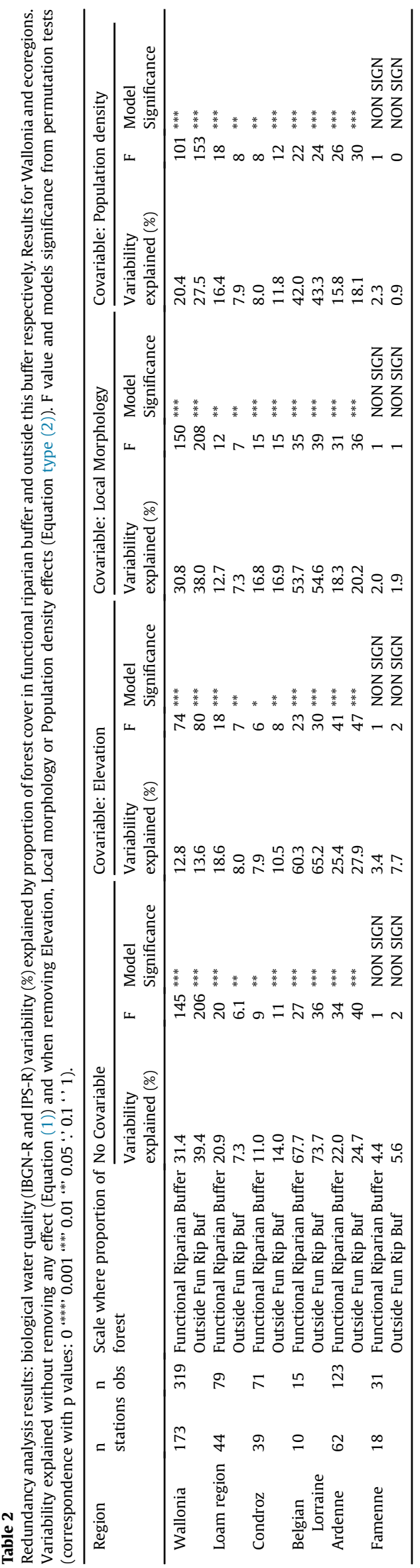

A

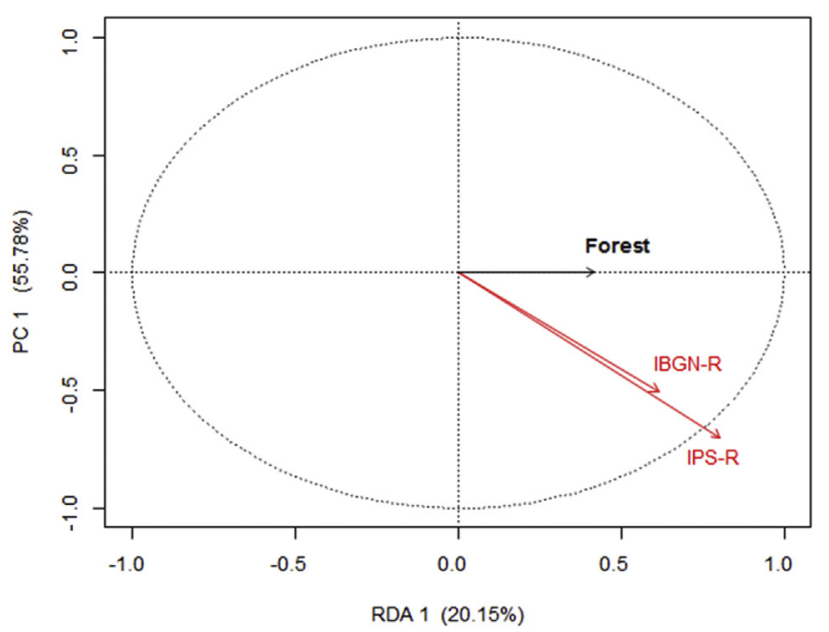

B

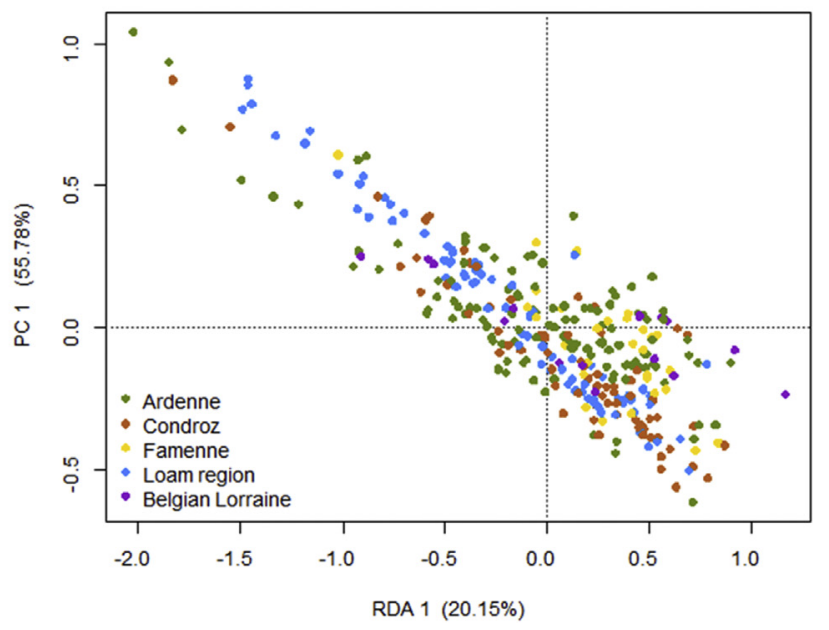

Fig. 5. RDA results showing the link between forest cover outside the riparian buffer when controlling for elevation and biological water quality indices (IBGN-R and IPS-R). $\mathrm{X}$-axis represents the constrained axis and $\mathrm{y}$-axis, the first residual component. (A) Variables correlation circle plot, (B) Individuals plot sorted per ecoregion.

\section{(Fig. S4).}

All models explain a relatively high proportion of biological water quality variability revealing that most factors driving water quality (or correlated to them) are considered. Models for the Belgian Lorraine and Loam region better explain biological water quality variability (13 and $29 \%$ residuals respectively) whereas residuals are higher at the regional scale (36\%) and for the Condroz or Ardenne regions (41\% and 50\% respectively).

As shown on Fig. 6, physico-chemical water quality explains on its own relatively high proportions of biological water quality variability: $40 \%$ in the Loam region, $19 \%$ in the Ardenne, $17 \%$ in the Condroz and $13 \%$ at the regional scale.

Forest cover explanation of biological water quality is often shared (i.e. is inseparable) with physico-chemical water quality and anthropogenic pressures (Fig. 6). This is especially true in Wallonia, Ardenne and Belgian Lorraine whereas this effect is in some cases proven to be relatively independent from anthropogenic pressures such as in the Condroz and Loam region.

PCA analysis (see details in supplementary materials, Fig. S4) shows that both IBGN-R and IPS-R are systematically opposed on the first principal component to anthropogenic pressures and several physico-chemical variables linked to lower water quality as total phosphorus, ammonium, sulfates, nitrites, suspended 


\section{Wallonia}

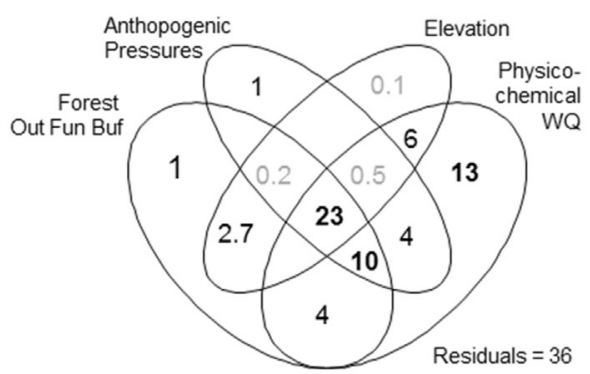

\section{Loam region}

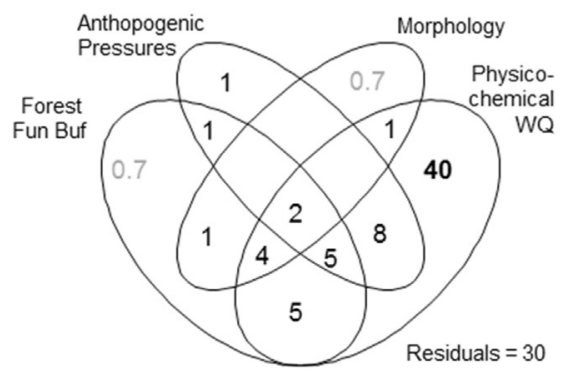

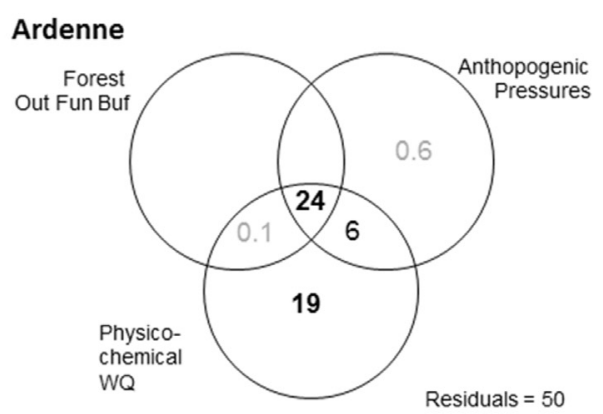
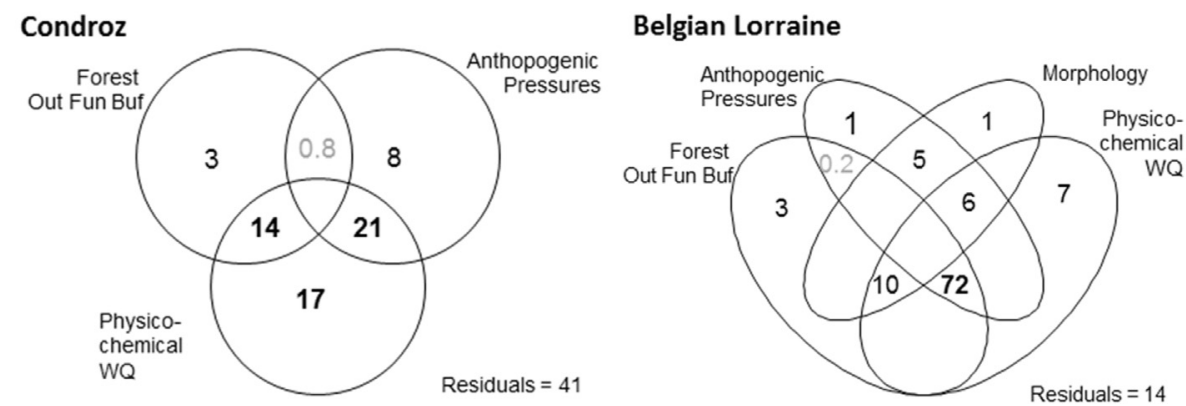

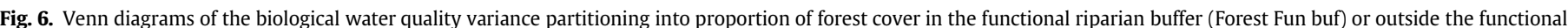

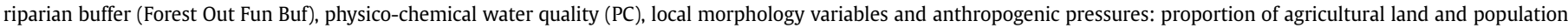

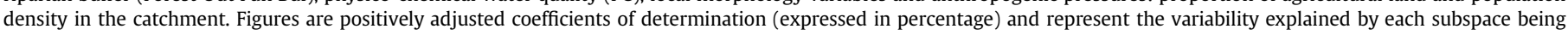
either a single variable or shared effect between two or more variables.

materials, chloride, dissolved organic carbon, water temperature. This is true in every extent specific case except for the Loam region and the Famenne where agricultural cover is not correlated with this first axe while population density is negatively correlated with high water quality indices values. Analysis across this first PCA component also shows that high biological water quality is systematically positively correlated with dissolved oxygen and forest cover proportion inside or outside the functional riparian buffer. Nitrates in most of situations are correlated with low biological water quality except for the Loam region and - to a lesser extent for the Condroz ecoregion. The second axis, which represents the differences between diatoms and macroinvertebrates, explains far less than the first component.

\section{Discussion}

\subsection{Preamble: forest cover in this study}

In order to fulfil this study objectives, we chose to study the "forest cover" through a proportion of forest cover in upstream catchment or functional riparian buffer. It includes various forests in terms of management, stand age, tree density, species combination, local conditions. Furthermore, studied catchments are what we can call "real-life" catchments with mixed land covers - with high variability that we exploit through statistical analyses - and various local conditions that we discuss and attempt to control in the same analyses (trough e.g. the ecoregion scale analysis). This renders results sometimes more difficult to interpret but also more linked to the landscape scale and therefore more connected to land planning.

\subsection{Forest cover link with biological water quality}

Several insights were derived while addressing the main objective of this paper being: at the regional scale and across five natural ecoregions, to quantify the forest cover effect on biological water quality indices at the catchment and riparian scales. First, forest cover is systematically related to higher biological water quality described by diatoms and macro-invertebrates communitybased indexes. This is true no matter the extent of study. This is interesting as we study relatively heterogeneous LULC distributions, and in particular, regarding distributions of cropland and grassland covers. This finding corroborates studies associating forest cover with higher biological water quality (contrasting with agriculture and urban LULC) (Dahm et al., 2013; Ding et al., 2013; Kosuth et al., 2010; Theodoropoulos et al., 2015). However, comparing studies in detail is tricky as scales of LULC characterisation, selected biological indices and control variables are often study specific.

Regarding the scale at which forest cover within stream catchments most influences stream water quality, results vary according the extent of study. Main trend - i.e. in Wallonia and for every ecoregion but the Loam region - is that the forest cover proportion in the area outside the functional riparian buffer slightly better explains the biological water quality than the proportion of forest cover in the functional riparian buffer. This trend is in line with several studies highlighting that catchment-wide disturbances are the most influential determinants of river ecological quality (Allan, 2004; Clapcott et al., 2012; Dahm et al., 2013; Marzin et al., 2013, 2012; Stephenson and Morin, 2009).

Regarding the quantification and significance of the forest cover link with biological water quality, results show that forest cover considered alone - explains around one third of the biological water quality at the regional scale and from 14 to $70 \%$ depending on the ecoregion studied. The Belgian Lorraine - were this link is the most demonstrated - is characterized by highly contrasted catchments and a relatively high biological water quality variation. Removing the influence of spatial autocorrelation and ecological factors decreases, at the Walloon scale, the biological water quality variability explained by forest cover computed outside the 
functional riparian buffer respectively from 39 to $14 \%$. This result is similar with the quantitative assessment of forest cover effect on physico-chemical water quality in Wallonia (Brogna et al., 2017a). Intra-ecoregion effect of elevation is, as expected, less important within the ecoregions as these are more homogeneous in that respect. Local morphology impact on forest cover explanation power of biological water quality is diverse according to the extent of study. Indeed, it is small or even negligible at the Walloon scale and for the Ardenne and Condroz ecoregions whereas it is more important in the Belgian Lorraine. The important effect in this ecoregion can be explained by the highly contrasted morphological profiles of local rivers. Population density effect on the relationships between forest cover and biological water quality is at every extent relatively important, reducing the proportion explained by forest cover (outside functional riparian buffer) from around one third at the Wallonia scale, in the Ardenne and Belgian Lorraine and slightly less in the Condroz. Non-significance of any model in the Famenne ecoregion might be due to the complexity of water flows through the limestone subsoil.

Quantification of independent and shared explanation power of biological water quality between forest cover and the physicochemical water quality, anthropogenic pressures (agriculture and population density) and local morphology reveals that physicochemical water quality explains on its own relatively high proportions of biological water quality variability. This finding is in line with Dahm et al. (2013)'results identifying physico-chemical water quality as one of the main discriminating factor of biological water quality. This renders interpretation even more complex as physicochemical water quality has been proven to be linked to LULC and forest in particular in Wallonia (Brogna et al., 2017a). This is also in line with the nutrient enrichment shown in European studies and in Wallonia [e.g. European Environment Agency (2012) or SPWDGO3-Direction de l'Etat Environnemental (2014)]. Our study also highlights that forest cover explanation of biological water quality is often inseparable from physico-chemical water quality and anthropogenic pressures. However, it is in some cases interestingly proven to be relatively independent from anthropogenic pressures such as in the Condroz and Loam region. In the Loam region, complementary analysis shows that the proportion of agricultural land (i.e. grassland and cropland) at the catchment scale is not proven to have any link (RDA models are non-significant, $p>.05$ ) with biological water quality whereas forest cover is at any spatial upstream unit scale. This finding is interesting in terms of land planning. Indeed, the fact that forests are mostly present in the functional riparian buffer in this ecoregion while relatively absent in the rest of the catchments - the Loam region is the less forested Walloon ecoregion - combined with agricultural models being non-significant at the catchment scale let us believe that the computed forest link with biological water quality represents a "real" forest effect. Furthermore, study of the functional riparian buffer LULC explanation power of water quality revealed that only cropland cover model was significant (i.e. not grassland cover, $\mathrm{p}>.05$ ) and explained a twice-lower proportion of variability than forest cover. Non significance of grassland cover effect model could be linked to the existing diversity of management. Indeed, some grassland are enriched with Nitrogen, Phosphorus and Potassium while other are not. Cattle grazing pressure might also influence water quality through fine sediments transfer to the stream.

Consequently, in these catchments, riparian forests should be protected because of their positive effect on biological water quality. This is in line with Tran et al. (2010) findings showing a stronger correlation between LULC and stream water quality at the 200-m riparian buffer than that of the watershed. These authors also suggest that the presence of a riparian buffer zone between streams and agricultural and urban areas might reduce contamination from non-point source pollution. On the other hand, the fact that we did not detect this preponderance of a riparian effect in the other ecoregions and at the regional scale suggests, as Stephenson and Morin (2009) or Harding et al. (1998) noted in their study, that maintenance or preservation of habitat fragments in the riparian zone will not be sufficient to preserve ecological instream quality from catchment-wide impacts. Rather, this requires protection measures at the catchment scale.

\subsection{Limitation, strengths of the study and perspectives}

Some limitations of this study should be pointed out. First, the approach hardly allows for quantitatively isolating a potentially "active" effect of forest cover (i.e., water purification per se) from a "passive" one directly linked to the degree of pressure of other LULC on water quality. Then, we chose to describe biological water quality through integrated indices used in the waterbody quality assessment in the EU-WFD context. These indices are designed to be as comparable as possible between regions and are simplified indicators. This limits the analysis' sharpness and using other information as biological traits could fine tune the analysis (Mondy and Usseglio-Polatera, 2013). In particular, as forest cover link with physico-chemical and biological water quality has been established in this study and in Brogna et al. (2017a), further studies could concentrate on biological traits in order to detail the forest cover impact on ecological processes of macroinvertebrates communities and eventually highlight trees species and management effects. However, we believe that the biological indices used in this study given their diversity (based on diatoms and macroinvertebrates communities) and their integrative character (of physical, chemical river quality status) are relevant to fulfil our study objectives. Furthermore, we derived ratios (by dividing biological indices by the reference value for the river type), increasing the comparability between ecoregions. We believe this study present the following strengths: (i) it is based on a relatively large public monitoring network data linked to the EU-WFD and thus monitored across Europe which makes it rather easily replicable in other European contexts, (ii) the database covers contrasted 'reallife' and heterogeneous catchments in Wallonia making the conclusions of this study more general, (iii) this study integrates physico-chemical and biological indices allowing to quantify the strong relationship between them, (iv) the different study extents (i.e. regional and sub-regional) allow to assess main regional trends and strengthen results while enhancing them according to local characteristics.

\section{Conclusion}

The main objective of this study was to quantify the forest cover link with biological water quality indices (macroinvertebrates and diatoms) at the riparian and catchment scales. This analysis was conducted for the entire Walloon region and across five natural ecoregions. Main results show that forest cover - considered alone - explains around $30 \%$ of the biological water quality at the regional scale and from 15 to $70 \%$ across ecoregions. Furthermore, it is systematically positively correlated with higher biological water quality. When modulating this explanation power by spatial, local morphological variations, or population density, it is still above $10 \%$. Partitioning variance shows that physico-chemical water quality is one of the main driver of biological water quality and that anthropogenic pressures often explain an important part of biological water quality. The proportion of forest cover in each catchment at the regional scale and across every ecoregions but the Loam region is more positively correlated with high water quality than similar analyses considering the proportion of forest cover in 
the riparian zones only. This suggests that catchment-wide impacts and $a$ fortiori catchment-wide protection measures are the main drivers of river ecological water quality. Distinctive results from the agricultural and highly human impacted Loam region showed that remaining riparian forests have a positive impact on water quality and should therefore be preserved. However, as waterbodies are below 'good status' overall in this ecoregion, this is not sufficient to restore good ecological instream quality. On the other hand, this preponderance of a riparian forest cover link with biological water quality was not found in the other ecoregions and at the regional scale suggesting that protection measures at the catchment scale are required.

\section{Acknowledgments:}

This work is connected to the Walloon Ecosystem Services platform (WALES) and the Belgian Ecosystems \& Society community of practice (www.beescommunity.be). We acknowledge the Walloon Public Service - DGO2, Surface Water Department and DGO3, Department of the Study of the Natural and Agricultural Environment - for providing physico-chemical and biological water quality datasets respectively. The authors acknowledge the Belgian Geographic National Institute for providing land cover dataset.

\section{Appendix A. Supplementary data}

Supplementary data related to this article can be found at https://doi.org/10.1016/j.jenvman.2018.01.017.

\section{References}

AFNOR, 2004. Qualité de l'eau: Détermination de l'indice biologique global normalisé (I.B.G.N.). Normalisation française NF T90-350. AFNOR, Paris, France.

AFNOR, 1985. Essai des eaux: Détermination de l'indice biologique global (I.B.G.). Normalisation française T90-350. AFNOR, Paris, France.

Alderweireld, M., Burnay, F., Pitchugin, M., Lecomte, H., 2015. Inventaire Forestier Wallon - Résultats 1994-2012. SPW, Jambes, Belgique.

Allan, J.D., 2004. Landscapes and riverscapes: the influence of land use on stream ecosystems. Annu. Rev. Ecol. Evol. Syst. 35, 257-284. https://doi.org/10.1146/ annurev.ecolsys.35.120202.110122.

Bere, T., Tundisi, J.G., 2010. Biological monitoring of lotic ecosystems: the role of diatoms. Braz. J. Biol. Rev. Brasleira Biol. 70, 493-502.

Borcard, D., Gillet, F., Legendre, P., 2011. In: Numerical Ecology with R, 2011 ed. Springer-Verlag New York Inc., New York.

Borrelli, P., Panagos, P., Märker, M., Modugno, S., Schütt, B., 2017. Assessment of the impacts of clear-cutting on soil loss by water erosion in Italian forests: first comprehensive monitoring and modelling approach. CATENA 149, 770-781. https://doi.org/10.1016/j.catena.2016.02.017.

Boyd, C., 2015. Water Quality - an Introduction.

Boyer-Rechlin, N., Bruland, G., Rechlin, M., 2016. Effects of agricultural land use on benthic macroinvertebrate communities and the applicability of family level bioassessment metrics in southern Illinois headwater streams. Trans. Ill State Acad. Sci. 109, 49-56.

Brogna, D., Michez, A., Jacobs, S., Dufrêne, M., Vincke, C., Dendoncker, N., 2017a. Linking forest cover to water quality: a multivariate analysis of large monitoring datasets. Water 9 (176). https://doi.org/10.3390/w9030176.

Brogna, D., Vincke, C., Brostaux, Y., Soyeurt, H., Dufrêne, M., Dendoncker, N., 2017b. How does forest cover impact water flows and ecosystem services? Insights from "real-life" catchments in Wallonia (Belgium). Ecol. Indic. 72, 675-685. https://doi.org/10.1016/j.ecolind.2016.08.011.

CEMAGREF, 1982. Etude des méthodes biologiques quantitatives d'appréciation de la qualité des eaux. Rapport Q.E. Lyon. A.F.B. Rhône-Méditerranée-Corse.

Chapman, D., 1992. Water Quality Assessment: a Guide to the Use of Biota, Sediments and Water in Environmental Monitoring. Chapman and Hall. ed, London, U.K.

Clapcott, J.E., Collier, K.J., Death, R.G., Goodwin, E.O., Harding, J.S., Kelly, D., Leathwick, J.R., Young, R.G., 2012. Quantifying relationships between land-use gradients and structural and functional indicators of stream ecological integrity. Freshw. Biol. 57, 74-90. https://doi.org/10.1111/j.1365-2427.2011.02696.x.

Dahm, V., Hering, D., Nemitz, D., Graf, W., Schmidt-Kloiber, A., Leitner, P., Melcher, A., Feld, C.K., 2013. Effects of physico-chemistry, land use and hydromorphology on three riverine organism groups: a comparative analysis with monitoring data from Germany and Austria. Hydrobiologia 704, 389-415. https://doi.org/10.1007/s10750-012-1431-3. de Oliveira, L.M., Maillard, P., de Andrade Pinto, É.J., 2016. Modeling the effect of land use/land cover on nitrogen, phosphorous and dissolved oxygen loads in the Velhas River using the concept of exclusive contribution area. Environ. Monit. Assess. 188 (333) https://doi.org/10.1007/s10661-016-5323-2.

Delgado, C., Pardo, I., García, L., 2012. Diatom communities as indicators of ecological status in Mediterranean temporary streams (Balearic Islands, Spain). Ecol. Indic. 15, 131-139. https://doi.org/10.1016/j.ecolind.2011.09.037.

DESCY, J.P., 1979. A new approach to water quality estimation using diatoms. Nova Hedwigia Beih. 64, 305-323.

Ding, S., Zhang, Y., Liu, B., Kong, W., Meng, W., 2013. Effects of riparian land use on water quality and fish communities in the headwater stream of the Taizi River in China. Front. Environ. Sci. Eng. 7, 699-708. https://doi.org/10.1007/s11783013-0528-x.

Dosskey, M.G., Vidon, P., Gurwick, N.P., Allan, C.J., Duval, T.P., Lowrance, R., 2010. The role of riparian vegetation in protecting and improving chemical water quality in Streams1. JAWRA J. Am. Water Resour. Assoc. 46, 261-277. https://doi.org/ 10.1111/j.1752-1688.2010.00419.x.

Dufrene, M., Legendre, P., 1991. Geographic structure and potential ecological factors in Belgium. J. Biogeogr. 257-266.

European Commission, 2000. Water Framework directive (2000/60/EC). Off. J. Eur. Commun. 1-72.

European Environment Agency, 2012. In: European Waters: Assessment of Status and Pressures. EEA report. European Environment Agency [u.a.], Copenhagen.

Fernandes, J.de F., Souza, A.L.T. de, Tanaka, M.O., 2014. Can the structure of a riparian forest remnant influence stream water quality? A tropical case study. Hydrobiologia 724, 175-185. https://doi.org/10.1007/s10750-013-1732-1.

Giorgio, A., De Bonis, S., Guida, M., 2016. Macroinvertebrate and diatom communities as indicators for the biological assessment of river Picentino (Campania, Italy). Ecol. Indic. 64, 85-91. https://doi.org/10.1016/j.ecolind.2015.12.001.

Giri, S., Qiu, Z., 2016. Understanding the relationship of land uses and water quality in Twenty First Century: a review. J. Environ. Manag. 173, 41-48. https:// doi.org/10.1016/j.jenvman.2016.02.029.

Haddadin, M.J., 2001. Water scarcity impacts and potential conflicts in the MENA region. Water Int. 26, 460-470. https://doi.org/10.1080/02508060108686947.

Harding, J.S., Benfield, E.F., Bolstad, P.V., Helfman, G.S., Jones, E.B.D., 1998. Stream biodiversity: the ghost of land use past. Proc. Natl. Acad. Sci. Unit. States Am. 95 14843-14847.

Hering, D., Johnson, R.K., Kramm, S., Schmutz, S., Szoszkiewicz, K., Verdonschot, P.F.M., 2006. Assessment of European streams with diatoms, macrophytes, macroinvertebrates and fish: a comparative metric-based analysis of organism response to stress. Freshw. Biol. 51, 1757-1785. https://doi.org/ 10.1111/j.1365-2427.2006.01610.x.

Herringshaw, C.J., Stewart, T.W., Thompson, J.R., Anderson, P.F., 2011. Land use, stream habitat and benthic invertebrate assemblages in a highly altered Iowa watershed. Am. Midl. Nat. 165, 274-293. https://doi.org/10.1674/0003-0031165.2.274.

Jackson, C.R., Leigh, D.S., Scarbrough, S.L., Chamblee, J.F., 2015. Herbaceous versus forested riparian vegetation: narrow and simple versus wide, woody and diverse stream habitat. River Res. Appl. 31, 847-857. https://doi.org/10.1002/ rra. 2783 .

Johnson, L., Richards, C., Host, G., Arthur, J., 1997. Landscape influences on water chemistry in Midwestern stream ecosystems. Freshw. Biol. 37, 193-208. https:// doi.org/10.1046/j.1365-2427.1997.d01-539.x.

Kail, J., Arle, J., Jähnig, S.C., 2012. Limiting factors and thresholds for macroinvertebrate assemblages in European rivers: empirical evidence from three datasets on water quality, catchment urbanization, and river restoration. Ecol. Indic. 18, 63-72. https://doi.org/10.1016/j.ecolind.2011.09.038.

Kosuth, P., Tormos, T., Cernesson, F., Lalande, N., Villeneuve, B., 2010. Assessing the role of riparian vegetation and land use on river ecological status using remote sensing and spatial modelling. In: SER: Proceedings 7th European Conference on Ecological Restoration. Avignon, France, 4 pp.

Legendre, P., Legendre, L., 2012. Chapter 11-Canonical analysis. In: Legendre, P.L (Ed.), Developments in Environmental Modelling, Numerical Ecology. Elsevier, pp. 625-710.

Lobo, E.A., Heinrich, C.G., Schuch, M., Wetzel, C.E., Ector, L., 2016. Diatoms as bioindicators in rivers. In: JR, O.N. (Ed.), River Algae. Springer International Publishing, pp. 245-271. https://doi.org/10.1007/978-3-319-31984-1_11.

Loh, J., Green, R.E., Ricketts, T., Lamoreux, J., Jenkins, M., Kapos, V., Randers, J., 2005 The Living Planet Index: using species population time series to track trends in biodiversity. Philos. Trans. R. Soc. Lond. B Biol. Sci. 360, 289-295. https:// doi.org/10.1098/rstb.2004.1584.

Mahler, R.L., Barber, M.E., 2017. Using benthic macro invertebrates to assess water quality in 15 watersheds in the Pacific Northwest, USA. Int. J. Sustain. Dev. Plann. 12, 51-60. https://doi.org/10.2495/SDP-V12-N1-51-60.

Marzin, A., Archaimbault, V., Belliard, J., Chauvin, C., Delmas, F., Pont, D., 2012 Ecological assessment of running waters: do macrophytes, macroinvertebrates, diatoms and fish show similar responses to human pressures? Ecol. Indic. 23, 56-65. https://doi.org/10.1016/j.ecolind.2012.03.010.

Marzin, A., Verdonschot, P.F.M., Pont, D., 2013. The relative influence of catchment riparian corridor, and reach-scale anthropogenic pressures on fish and macroinvertebrate assemblages in French rivers. Hydrobiologia 704, 375-388. https://doi.org/10.1007/s10750-012-1254-2.

Meybeck, M., 2003. Global analysis of river systems: from Earth system controls to Anthropocene syndromes. Philos. Trans. R. Soc. B Biol. Sci. 358, 1935-1955. https://doi.org/10.1098/rstb.2003.1379. 
Michez, A., Piégay, H., Lejeune, P., Claessens, H., 2017. Multi-temporal monitoring of a regional riparian buffer network $(>12,000 \mathrm{~km})$ with LiDAR and photogrammetric point clouds. J. Environ. Manag. https://doi.org/10.1016/ j.jenvman.2017.02.034.

Millennium Ecosystem Assessment, 2005. Ecosystems and Human Well-being. Synthesis. Island Press.

Mondy, C.P., Usseglio-Polatera, P., 2013. Using conditional tree forests and life history traits to assess specific risks of stream degradation under multiple pressure scenario. Sci. Total Environ. 461, 750-760. https://doi.org/10.1016/ j.scitotenv.2013.05.072.

Naiman, R.J., Decamps, H., McClain, M.E., 2010. Riparia: Ecology, Conservation, and Management of Streamside Communities. Academic Press.

Neary, D.G., Ice, G.G., Jackson, C.R., 2009. Linkages between forest soils and water quality and quantity. For. Ecol. Manag. 258, 2269-2281. https://doi.org/10.1016/ j.foreco.2009.05.027.

Noirfalise, A., 1988, 3:25. Les régions naturelles de la Belgique, vol. 23. G.E.O.

Oksanen, J., Blanchet, F.G., Friendly, M., Kindt, R., Legendre, P., McGlinn, D. Minchin, P.R., O'Hara, R.B., Simpson, G.L., Solymos, P., Stevens, M.H.H., Szoecs, E., Wagner, H., 2017. Vegan: Community Ecology Package.

Pacheco, F.A.L., Sanches Fernandes, L.F., 2016. Environmental land use conflicts in catchments: a major cause of amplified nitrate in river water. Sci. Total Environ. 548-549, 173-188. https://doi.org/10.1016/j.scitotenv.2015.12.155.

Pacheco, F.A.L., Santos, R.M.B., Sanches Fernandes, L.F., Pereira, M.G., Cortes, R.M.V. 2015. Controls and forecasts of nitrate yields in forested watersheds: a view over mainland Portugal. Sci. Total Environ. 537, 421-440. https://doi.org/ 10.1016/j.scitotenv.2015.07.127.

Peres-Neto, P.R., Legendre, P., Dray, S., Borcard, D., 2006. Variation partitioning of species data matrices: estimation and comparison of fractions. Ecology 87 2614-2625. https://doi.org/10.1890/0012-9658(2006)87[2614:VPOSDM 2.0.CO;2.

Riva-Murray, K., Bode, R.W., Phillips, P.J., Wall, G.L., 2002. Impact source determination with biomonitoring data in New York state: concordance with environmental data. Northeast. Nat. 9, 127-162. https://doi.org/10.2307/3858392.

Santos, R.M.B., Sanches Fernandes, L.F., Pereira, M.G., Cortes, R.M.V., Pacheco, F.A.L 2015. Water resources planning for a river basin with recurrent wildfires. Sci. Total Environ. 526, 1-13. https://doi.org/10.1016/j.scitotenv.2015.04.058.

Scarsbrook, M.R., Halliday, J., 1999. Transition from pasture to native forest land-use along stream continua: effects on stream ecosystems and implications for restoration. N. Z. J. Mar. Freshw. Res. 33, 293-310. https://doi.org/10.1080/ 00288330.1999.9516878.

Shakesby, R.A., 2011. Post-wildfire soil erosion in the Mediterranean: review and future research directions. Earth Sci. Rev. 105, 71-100. https://doi.org/10.1016/ j.earscirev.2011.01.001.

Sharma, R.C., Rawat, J.S., 2009. Monitoring of aquatic macroinvertebrates as bioindicator for assessing the health of wetlands: a case study in the Central Himalayas, India. Ecol. Indic. 9, 118-128. https://doi.org/10.1016/ j.ecolind.2008.02.004.

Sheldon, F., Peterson, E.E., Boone, E.L., Sippel, S., Bunn, S.E., Harch, B.D., 2012 Identifying the spatial scale of land use that most strongly influences overall river ecosystem health score. Ecol. Appl. Publ. Ecol. Soc. Am. 22, 2188-2203.

Sliva, L., Dudley Williams, D., 2001. Buffer zone versus whole catchment approaches to studying land use impact on river water quality. Water Res. 35, 3462-3472. https://doi.org/10.1016/S0043-1354(01)00062-8.

Soininen, J., Könönen, K., 2004. Comparative study of monitoring South-Finnish rivers and streams using macroinvertebrate and benthic diatom community structure. Aquat. Ecol. 38, 63-75. https://doi.org/10.1023/B:
AECO.0000021004.06965.bd

Sponseller, R.A., Benfield, E.F., Valett, H.M., 2001. Relationships between land use, spatial scale and stream macroinvertebrate communities. Freshw. Biol. 46, 1409-1424. https://doi.org/10.1046/j.1365-2427.2001.00758.x.

SPW - DGO3, n.d. Le réseau de surveillance de la qualité des eaux de surface Portail "Directive-cadre sur l'Eau" - [WWW Document]. URL http://eau. wallonie.be/spip.php?article120 (accessed 4.4.17).

SPW-DGO3-Direction de l'Etat Environnemental, 2016. Deuxièmes Plans de gestion des Districts Hydrographiques - Document général. Mise en œuvre de la Directive-cadre sur l'Eau (2000/60/CE) - Région wallonne. SPW.

SPW-DGO3-Direction de l'Etat Environnemental, 2014. Les indicateurs clés de l'environnement Wallon 2014. Rapport sur l'état de l'environnement wallon, Namur, Belgique.

Statistics Belgium, n.d. Structure de la population [WWW Document]. URL http:// statbel.fgov.be/fr/statistiques/chiffres/population/structure/(accessed 5.13.17).

Stephenson, J.M., Morin, A., 2009. Covariation of stream community structure and biomass of algae, invertebrates and fish with forest cover at multiple spatial scales. Freshw. Biol. 54, 2139-2154. https://doi.org/10.1111/j.13652427.2008.02142.x.

Stoate, C., Boatman, N.D., Borralho, R.J., Carvalho, C.R., Snoo, G.R., de Eden, P., 2001. Ecological impacts of arable intensification in Europe. J. Environ. Manag. 63, 337-365. https://doi.org/10.1006/jema.2001.0473.

Tanaka, M.O., Souza, A.L.T. de, Moschini, L.E., Oliveira, A.K. de, 2016. Influence of watershed land use and riparian characteristics on biological indicators of stream water quality in southeastern Brazil. Agric. Ecosyst. Environ. 216, 333-339. https://doi.org/10.1016/j.agee.2015.10.016.

TEEB, 2010. The Economics of Ecosystems and Biodiversity: Ecological and Economic Foundations. Pushpam Kumar, Earthscan, London and Washington.

Theodoropoulos, C., Aspridis, D., Iliopoulou-Georgudaki, J., 2015. The influence of land use on freshwater macroinvertebrates in a regulated and temporary Mediterranean river network. Hydrobiologia 751, 201-213. https://doi.org/ 10.1007/s10750-015-2187-3.

Tong, S.T.Y., Chen, W., 2002. Modeling the relationship between land use and surface water quality. J. Environ. Manag. 66, 377-393.

Tran, C.P., Bode, R.W., Smith, A.J., Kleppel, G.S., 2010. Land-use proximity as a basis for assessing stream water quality in New York State (USA). Ecol. Indic. 10, 727-733. https://doi.org/10.1016/j.ecolind.2009.12.002.

UN-Water, 2014. A Post-2015 Global Goal for Water: Synthesis of Key Findings and Recommendations from UN-water.

Valle Junior, R.F., Varandas, S.G.P., Pacheco, F.A.L., Pereira, V.R., Santos, C.F., Cortes, R.M.V., Sanches Fernandes, L.F. 2015. Impacts of land use conflicts on riverine ecosystems. Land Use Pol. 43, 48-62. https://doi.org/10.1016/ j.landusepol.2014.10.015.

Vanden Bossche, J.-P., 2005. Procédures et instructions pour l'organisation et l'exécution des prélèvements et des analyses de macroinvertébrés aquatiques en Région wallonne. WPS - DGRNE - Centre de Recherche de la Nature, des Forêts et du Bois.

Vondracek, B., Blann, K.L., Cox, C.B., Nerbonne, J.F., Mumford, K.G., Nerbonne, B.A. Sovell, L.A., Zimmerman, J.K.H., 2005. Land use, spatial scale, and stream systems: lessons from an agricultural region. Environ. Manag. 36, 775-791. https:// doi.org/10.1007/s00267-005-0039-z.

Vörösmarty, C.J., McIntyre, P.B., Gessner, M.O., Dudgeon, D., Prusevich, A., Green, P., Glidden, S., Bunn, S.E., Sullivan, C.A., Liermann, C.R., Davies, P.M., 2010. Global threats to human water security and river biodiversity. Nature 467, 555-561. https://doi.org/10.1038/nature09440. 